\title{
Optimal Mixing Ratio of Seafood Sauce with Blue Crab (Portunus trituberculatus)
}

\author{
Kyong-Tae Park, Min-Soo Kim', Byung-Min Kwon ${ }^{1}$, Eun-Soo Shin ${ }^{1}$, \\ Hong-Soo Ryu ${ }^{1}$ and Dae-Heung Jang ${ }^{2}$ \\ Department of Hotel Culinary Art and Nutrition, Kaya University, Gimhae 621-070, Korea \\ ${ }^{1}$ Faculty of Food Science and Biotechnology, Pukyong National University, Busan 608-737, Korea \\ ${ }^{2}$ Faculty of Mathematical Science, Pukyong National University, Busan 608-737, Korea
}

\begin{abstract}
This study optimized the mixing ratios of seafood sauce with blue crab for maximal sensory attributes using a response surface methodology with central composite design. It evaluated sensory appeal, nutritional value, and some rheological properties. The optimal formulation appeared to be $252 \mathrm{~g}$ of tomato paste, $78 \mathrm{~g}$ of chopped garlic, and $519 \mathrm{~g}$ of blue crab block; this ratio resulted in a predicted sensory score of 5.7 (on a 7-point scale) for overall acceptability. Addition of blue crab block increased moisture, ash, and protein contents in various sauces, but fat contents were similar in every sauce. Major free amino acids such as glutamic acid, phosphoserine, asparagine, and arginine composed about $60 \%$ of the total amino acid content. Standard and optimized sauces were red and light yellow, and those color values were significantly higher than in American-style sauces. Optimal viscosity was half the value of American-style sauces; more blue crab block added to the sauce resulted in lower viscosity. Adding this sauce to seafood dishes will likely aid development of flavoring substances.
\end{abstract}

Key words: Blue crab, Portunus trituberculatus, Response surface methodology, Seafood sauce

\section{Introduction}

Seafood is a healthy and attractive addition to a well-balanced life because of its high nutritional value and sensory qualities. Koreans enjoy seafood but Korean dishes are limited to a few foods: sashimi (such as raw meat dishes), and hot stew. In contrast, Westerners enjoy steamed or fried seafood with special sauces, e.g., American-style sauce (Choi, 2002; Lee, 2004) on crustaceans such as lobster, king crab, and tiger shrimp. Although sauces are effective ways to improve flavor, sauces are not widely accepted in Korea because Koreans have not enjoyed the greasy flavor in western-style sauces $(\mathrm{Oh}, 2000$; Lee et al., 2002). Using sauces on seafood products may be the determining factor in development of new seafood dishes that maintain nutritional and sensory qualities. Blue crab (Portunus trituberculatus) is popular in Korea because of its umami (glutamate) flavor (Kim et al., 1990; Han et al., 1996; Lee et al., 2001), so if sauces using blue crab are optimized, trends in seafood consumption could change. A

\footnotetext{
${ }^{*}$ Corresponding author: hsryu@pknu.ac.kr
}

response surface methodology (RSM) was applied to achieve successful preparation of these seafood sauces. RSM is a promising tool used during the design of new products in the food industry (Hu, 1999; Lee et al., 2000). Researchers have applied RSM to the preparation of brown sauce (Kim and Lee, 1999) and red pepper jam (Lee and Jeong, 1999) and proved its value.

The goal of this study was to use RSM central composite design to examine the optimal ingredient ratio of seafood sauce with blue crab for maximal sensory appeal. In order to compare the food quality of blue crab sauce, the nutritional value and some rheological properties of American-style sauce were also examined.

\section{Sample preparation}

\section{Materials and Methods}

Frozen blue crab (Portunus trituberculatus) and all other ingredients (garlic, onions, tomato paste, water, carrots, flour, butter, white wine, celery, and thyme) were obtained at a local market. The blue crab sauce was prepared according to a modified recipe of 
American-style sauce as shown in Fig. 1.

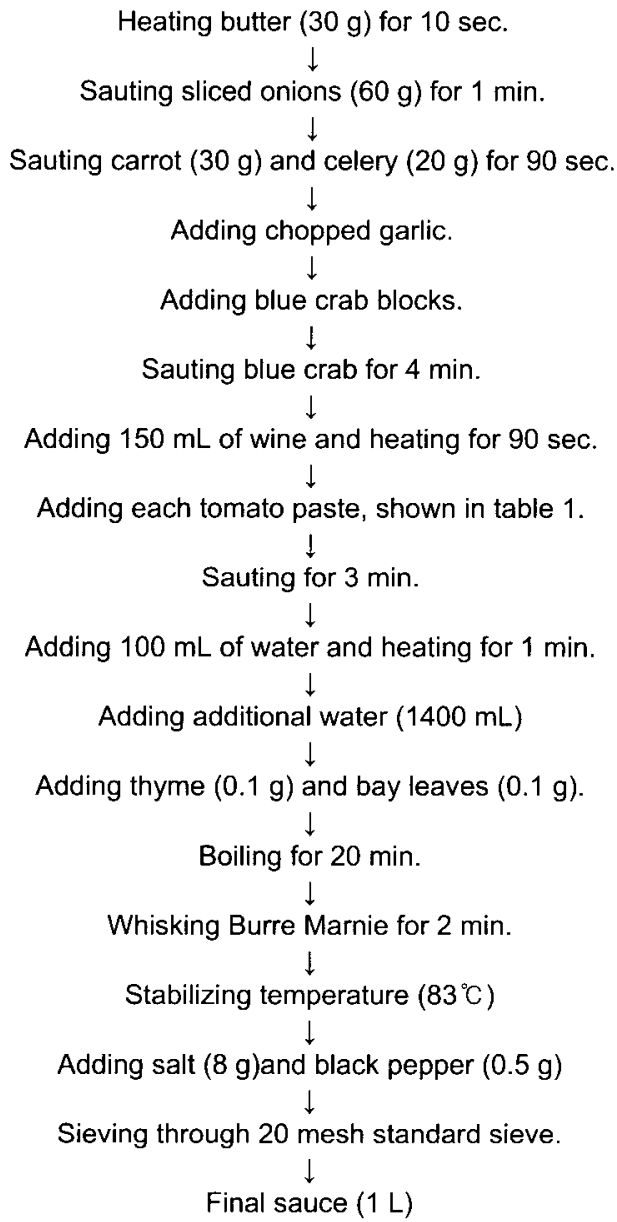

Fig. 1. Flowsheet for the blue crab sauce preparation.

\section{Experimental design and sensory tests}

Ten experiments were performed based on a central composite design with three variables and three levels for each variable. Independent variables included tomato paste (X1), chopped garlic (X2), and blue crab block (X3) with shell removed and cut into four pieces. Table 1 presents the factor levels and actual values. Variable levels were selected to include ranges for a typical American-style sauce. Table 2 presents the experimental design. A consumer-type sensory test involved panelists $(\mathrm{n}=53)$ testing samples. Panelists were selected randomly from among departmental undergraduate students, graduate students, and faculty members. Sauces were initially subjected to overall sensory evaluation by a panel, taking into consideration the following response variables: taste (Y1), color (Y2), odor (Y3), viscosity (Y4), and overall acceptability (Y5). A rating scale of 1 to 7 points $(1=$ extremely dislike, $4=$ neither dislike nor
Table 1. Levels of factors for the response surface design in the actual and the coded values

\begin{tabular}{lcccc}
\hline & \multirow{2}{*}{ Factors } & \multicolumn{3}{c}{ Coded values } \\
\cline { 3 - 5 } & Factor & -1 & 0 & 1 \\
\cline { 3 - 5 } & & \multicolumn{3}{c}{ Actual values } \\
\hline Tomato paste $(\mathrm{g})$ & $\mathrm{X}_{1}$ & 190 & 250 & 310 \\
Chopped garlic(g) & $\mathrm{X}_{2}$ & 42 & 68 & 78 \\
Blue crab(g) & $\mathrm{X}_{3}$ & 281 & 400 & 519 \\
\hline
\end{tabular}

like, $7=$ extremely like) was used to select the best ratio of ingredients (Kim et al., 2000). The functional relationship between the mixture ratio and sensory attributes was expressed using a quadratic canonical polynomial model (Scheffe, 1958; Prinyawiwwatkul, 1997).

\section{Nutritional evaluation}

Standard AOAC procedures (1990) were used to determine moisture, crude fat, crude protein $(\mathrm{N} \times$ 6.25), and ash; all analyses were done in triplicate. Free amino acid profiles and contents were determined using 5'-sulfosalicylic acid (SSA) deproteinized samples of $80 \%$ ethanol extracts with an amino acid analyzer (Biochrom Pharmacia Biotech, Berlin, Germany) loaded with lithium buffer ( $\mathrm{pH} 2.2$ ). The OPDA method (Church et al., 1983) was used to estimate total free amino acid content, expressed as D.L-lysine equivalents. The Van Laack method (1996) was used with a colorimeter (JC 801; Color Techno System Co., Tokyo, Japan) to measure Hunter's color value; standard plate values of $\mathrm{L}$, a, and $b$ were $93.73,-0.12$, and 0.11 , respectively. The RVDV-II+ digital viscometer (Brookfield Engineering, Middleboro, MA, USA) measured viscosity using spindle CP 52 in triplicate at $4^{\circ} \mathrm{C}$.

\section{Statistical analysis}

Tukey tests and analyses of variance (ANOVA) using MINITAB (Minitab, 2000) were used to evaluate data about proximate composition, color value, viscosity, and free amino acid content.

\section{Results and Discussion}

Sensory tests and the response surface methodology

To determine the most favorable acceptability, ratios of American-style seafood sauce with blue crab block were tested according to sensory descriptors (taste, color, odor, viscosity, and overall acceptability; see Table 2) as dependent variables (Y1-Y5). Relationships between these dependent variables and the independent variables such as tomato paste (X1), chopped garlic (X2), and blue crab blocks (X3) can 
Table 2. Central composite design for the optimization of blue crab sauce

\begin{tabular}{cccc}
\hline \multirow{2}{*}{$\begin{array}{c}\text { Formulation } \\
\text { number }\end{array}$} & $\begin{array}{c}\text { Tomato paste } \\
\left(\mathrm{X}_{1}\right)\end{array}$ & $\begin{array}{c}\text { Ingredients of sauce } \\
\left(\mathrm{X}_{2}\right)\end{array}$ & $\begin{array}{c}\text { Garlic } \\
\left(\mathrm{X}_{3}\right)\end{array}$ \\
\hline 1 & 1 & -1 & 1 \\
2 & 0 & 0 & 0 \\
3 & 1 & 1 & -1 \\
4 & -1 & 1 & 1 \\
5 & 0 & 0 & 0 \\
6 & 1 & 1 & 1 \\
7 & -1 & -1 & 1 \\
8 & -1 & 1 & -1 \\
9 & 1 & -1 & -1 \\
10 & -1 & -1 & -1 \\
\hline
\end{tabular}

Experimental runs were performed in random order by MINITAB (Minitab, 2000)

be expressed by the following regression equation using quadratic canonical polynomial models (Scheffe, 1958; Prinyawiwatkul, 1997):

$$
\mathrm{Y}=\mathrm{b}_{1} \mathrm{X}_{1}+\mathrm{b}_{2} \mathrm{X}_{2}+\mathrm{b}_{3} \mathrm{X}_{3}+\mathrm{b}_{12} \mathrm{X}_{1} \mathrm{X}_{2}+\mathrm{b}_{13} \mathrm{X}_{1} \mathrm{X}_{3}+\mathrm{b}_{23} \mathrm{X}_{2} \mathrm{X}_{3}
$$

Where $\mathrm{Y}=$ predicted dependent variables, $\mathrm{X}=$ independent variables, $X_{\mathrm{i}} \mathrm{X}_{\mathrm{j}}=$ interaction of independent variables, and $b_{i}, b_{i j}=$ regression coefficients. The multiple regression equations are shown in Table 3.

Chopped garlic (X2) made a significant contribution to sauce taste (Y1) and produced the highest regression constant ( $\mathrm{b} 2=0.9479$ ); regression constants for tomato paste $(\mathrm{b} 1=0.3854)$ and blue crab block (b3 $=0.2188$ ) were comparatively very low, revealing that these variables were secondary factors. Generally, the initial stage of designing a new food product requires a procedure that uses sensory testing to determine optimal mixing ratios (Fishken, 1983; Sidel and Stone, 1983). It is practically impossible to optimize ingredient ratios for all maximum sensory descriptors, but it is possible to predict results for close-to-ideal mixing ratios (Moskowitz, 1994). Therefore, when the desirability function (d) was
0.95 , the optimization response curve produced a desirable mixing ratio of 0.0100 (tomato paste): 0.5032 (chopped garlic):1.000 (blue crab block), producing a 4.9 sensory value. In this case, "desirability function" meant that if a sample was ranked 7 (extremely like) on the questionnaire, its expected relative value was assumed to be 1 (Minitab, 2000).

Similar to other tomato products, tomato paste (b1=0.510) and chopped garlic (b2 $=0.531)$ acted as a primary factor for color (Y2); blue crab block had no significant effect on color development $(b 3=0.073)$. The optimal mixing ratio for color was 0.2152 (tomato paste):0.8672 (chopped garlic):0.9716 (blue crab block), providing an expected sensory attribute value of $6.2(\mathrm{~d}=0.88)$.

Garlic (b2 $=0.3854)$ acted as a primary factor for odor (Y3); tomato paste $(\mathrm{b} 1=0.1146)$ and blue crab (b3 $=0.0104)$ had less effect. These results can be explained by how the pungent taste of garlic affected the odor of the entire sauce. The optimal odor response optimization ratio was -0.7623 (tomato paste): 0.8988 (chopped garlic): -0.9467 (blue crab block), providing an expected sensory value of $6.9(\mathrm{~d}=0.69)$.

Tomato paste $(\mathrm{bl}=0.4583)$ had a greater effect on sauce viscosity (Y4) than garlic $(\mathrm{b} 2=0.1875)$ or blue crab (b3=-0.2083), probably due to the plentiful pectic substance being dissolved into the sauce that resulted in high viscosity during sauce preparation. The optimal viscosity mixing ratio was 0.1844 (tomato paste):-0.6215 (chopped garlic):-1.0 (blue crab block); this produced the lowest sensory value (5.44) among the sensory attributes $(d=0.75)$.

As with taste and odor, garlic (b2 $=0.8466)$ was the most important ingredient variable affecting overall acceptability (Y5); tomato paste $(\mathrm{b} 1=0.5521)$ was second, and blue crab block produced a very low regression constant $(b 3=0.1771)$. The optimal ratio for overall acceptability was 0.2093 (tomato paste): 0.9268 (chopped garlic):0.9218 (blue crab block), resulting in a 5.67 sensory value $(\mathrm{d}=0.79)$.

Table 3. Regression for each dependent sensory attributes of the sauce from consumer acceptability test.

\begin{tabular}{|c|c|c|}
\hline Response variables & p-value ${ }^{2}$ & $\mathbf{R}^{2}(\%)$ \\
\hline Taste & & \\
\hline $\begin{array}{l}Y_{1}=4.370+0.3854 X_{1}+0.9479 X_{2}+0.2188 X_{3}-0.3021 X_{1} X_{1}-0.3646 X_{1} X_{2}-0.3021 X_{1} X_{3}-0.3229 X_{2} X_{3} \\
\text { Color }\end{array}$ & 0.000 & 45.2 \\
\hline $\begin{array}{l}Y_{2}=5.458+0.510 X_{1}+0.531 X_{2}+0.073 X_{3}-1.031 X_{1} X_{1}-0.052 X_{1} X_{2}+0.031 X_{1} X_{3}+0.177 X_{2} X_{3} \\
\text { Odor }\end{array}$ & 0.000 & 33.8 \\
\hline $\begin{array}{l}Y_{3}=4.583+0.1146 X_{1}+0.3854 X_{2}+0.0104 X_{3}+0.11458 X_{1} X_{1}-0.0729 X_{1} X_{2}+0.0937 X_{1} X_{3}-0.0521 X_{2} X_{3} \\
\text { Viscosity }\end{array}$ & 0.031 & 12.6 \\
\hline $\begin{array}{l}Y_{4}=5.0833+0.4583 X_{1}+0.1875 X_{2}-0.2083 X_{3}-0.5833 X_{1} X_{1}-0.1042 X_{1} X_{2}+0.3333 X_{1} X_{3}+0.3958 X_{2} X_{3} \\
\text { Overall acceptability }\end{array}$ & 0.000 & 21.3 \\
\hline$Y_{5}=4.833+0.5521 X_{1}+0.8446 X_{2}+0.1771 X_{3}-0.5729 X_{1} X_{1}-0.3854 X_{1} X_{2}-0.1562 X_{1} X_{3}-0.1354 X_{2} X_{3}$ & 0.000 & 52.3 \\
\hline
\end{tabular}


Determination of the sensory attribute most important to consumers would be valuable to the food industry. In general, each sensory attribute affects overall acceptability (Love, 1994); while they do not all affect overall acceptability in the same way, overall acceptability can be helpful in finding optimal ratios (Sidel et al., 1994). To optimize ingredient levels by overall acceptability, maximum values of tomato paste on the secondary curve (taste, color, and viscosity) and garlic (taste and odor) were applied. This solution involved an ingredient ratio of 0.0349 (tomato paste):1.0 (chopped garlic):1.0 (blue crab block); actual values were $252 \mathrm{~g}, 78 \mathrm{~g}$, and $519 \mathrm{~g}$, respectively. These quantities resulted in a sensory value of 5.74 , which corresponded to a desirability equal to 1 and adequate in terms of sensory acceptability.

\section{Proximate composition and physical evaluation of seafood sauces}

Viscosity and color values are important in quality standard evaluation of sauce prepared in food service. Therefore, it was important to consider moisture content and proximate composition, which could affect the viscosity of composite food products, when assessing the benefits of different ingredients.

The proximate composition of optimized seafood sauce was compared to the control sauce without blue crab block and the American-style sauce (Table 4). Moisture content $\left(p=0.000, R^{2}=95.84 \%\right)$ did not differ between the optimized and the American-style sauce, but the control sauce had slightly higher moisture content. These small differences in moisture content had no relationship to viscosity; moisture content in all sauces varied from 87 to $88 \%$ and comparison revealed that they were thicker than consommé (98\%; Jeong et al., 2000). These results are similar to other findings ( $86.4 \%$; Lee, 2004). The optimized and American-style sauces were higher in protein than the control sauce based on dry content $\left(p=0.001, R^{2}=98.07 \%\right)$, probably a result of the proteinous food-stuffs used in the American-style sauce (lobster head, crab legs, etc.) and the optimized sauce (blue crab block). Lee et al. (2002) reported that crude protein content in brown sauce ranged from 1.9 to $2.5 \%$ (9.4-12.3\% based on dry content) and Lee (2004) reported $2.47 \%$ (17.9\% based on dry content). The control sauce, which lacked blue crab block, had a protein content similar to that reported by Lee (2004), and both the American-style and control sauces had a protein content almost two times higher than brown sauce. The control and optimized sauces had sig-nificantly higher crude fat content than the American-style sauce $\left(p=0.002, \mathrm{R}^{2}=93.54 \%\right)$, probably a result of using butter during sauce preparation. Ash content exhibited differences similar to moisture content. Carbohydrate analysis revealed that the optimized sauce had the lowest content based on wet and/or dry measurements, while the control and American-style sauces exhibited similar protein contents. The blue crab block had an effect on carbohydrate content, influencing sauce viscosity; it diluted sauce density and lowered carbohydrate content.

Table 4 presents the color value results; the optimized and control sauces were lighter than the American-style sauce, but the optimized sauce had slightly higher $L^{*}$ values $\left(p=0.000, R^{2}=96.81 \%\right)$, indicating that the optimized sauce was slightly bright and the American-style sauce was darker or gray. In contrast, the optimized and control sauces exhibited significantly higher $a^{*}$ (redness) values $\left(\mathrm{p}=0.000, \mathrm{R}^{2}=\right.$ 99.61) compared to the American-style sauce. The optimized sauce had a higher tomato paste content than the American-style sauce, which might have caused the difference in redness. Sauces treated with blue crab block and tomato paste (optimized) and those with only tomato paste (control) had higher $b^{*}$

Table 4. Proximate composition, color values and viscosity of sample sauces ${ }^{a}$

\begin{tabular}{|c|c|c|c|c|c|c|c|c|}
\hline \multirow[b]{2}{*}{ Sample } & \multirow[b]{2}{*}{$\begin{array}{c}\text { Moisture } \\
(\%)\end{array}$} & \multirow[b]{2}{*}{$\begin{array}{c}\text { Crude protein } \\
(\%)\end{array}$} & \multirow[b]{2}{*}{$\begin{array}{c}\text { Crude Fat } \\
(\%)\end{array}$} & \multirow{2}{*}{$\begin{array}{l}\text { Crude Ash } \\
(\%)\end{array}$} & \multicolumn{3}{|c|}{ Color } & \multirow{2}{*}{$\begin{array}{c}\text { Viscosity } \\
60 \text { RPM } \\
\text { at } 4^{\circ} \mathrm{C}\end{array}$} \\
\hline & & & & & $\mathrm{L}$ & a & b & \\
\hline $\begin{array}{l}\text { American } \\
\text { sauce }\end{array}$ & $86.95 a \pm 0.03$ & $\begin{array}{c}3.465 \pm 0.22 \\
(26.55) \mathrm{a}\end{array}$ & $\begin{array}{c}1.96 \pm 0.01 \\
(15.02) a\end{array}$ & $\begin{array}{c}1.165 \pm 0.05 \\
(8.93) \mathrm{a}\end{array}$ & $37.49 a \pm 0.30$ & $3.00 a \pm 0.37$ & $23.69 a \pm 0.91$ & $120.5 a \pm 3.0$ \\
\hline $\begin{array}{l}\text { Control }^{b} \\
\text { sauce }\end{array}$ & $88.58 \mathrm{ab} \pm 0.02$ & $\begin{array}{c}2.045 \pm 0.02 \\
(17.90) \mathrm{c}\end{array}$ & $\begin{array}{c}2.67 \pm 0.17 \\
(23.38) \mathrm{c}\end{array}$ & $\begin{array}{c}0.95 \pm 0.01 \\
(8.32) \mathrm{a}\end{array}$ & $39.98 b \pm 0.55$ & $11.17 c \pm 0.10$ & $31.44 \mathrm{~b} \pm 0.80$ & $106.4 b \pm 10.2$ \\
\hline $\begin{array}{l}\text { Optimized } \\
\text { c sauce }\end{array}$ & $87.51 \mathrm{a} \pm 0.06$ & $\begin{array}{c}3.315 \pm 0.09 \\
(26.54) \mathrm{a}\end{array}$ & $\begin{array}{c}3.14 \pm 0.36 \\
(25.1) \mathrm{c}\end{array}$ & $\begin{array}{c}1.32 \pm 0.11 \\
(10.57) \mathrm{b} \\
\end{array}$ & $41.78 \mathrm{~b} \pm 0.08$ & $9.687 c \pm 0.25$ & $32.23 b \pm 0.53$ & $52.0 c \pm 4.3$ \\
\hline
\end{tabular}

${ }^{a}$ Means within a column with different superscripts are significantly different $(\mathrm{p}<0.05)$

${ }^{\mathrm{b}}$ Tomato paste : chopped garlic : blue crab block $=267 \mathrm{~g}: 63 \mathrm{~g}: 0 \mathrm{~g}$

${ }^{\mathrm{C}}$ Tomato paste $:$ chopped garlic $:$ blue crab block $=252 \mathrm{~g}: 78 \mathrm{~g}: 519 \mathrm{~g}$

Data in parenthesis mean $\%$ on $100 \mathrm{~g}$ solid. 
values than the American-style sauce. Han et al. (1996) reported a very high $b^{*}$ value (nitrogenous extracts) from blue crab block, so tomato paste and blue crab extracts significantly enhanced $b^{*}$ values in the optimized sauce $\left(\mathrm{p}=0.000, \mathrm{R}^{2}=93.94\right)$.

Viscosity of the optimized sauce was half the viscosity of the control or American-style sauces at $60 \mathrm{RPM}\left(\mathrm{p}=0.000, \mathrm{R}^{2}=96.11 \%\right)$ and $4^{\circ} \mathrm{C}$. Increased blue crab extract in sauces resulted in lower viscosity (Table 4); the blue crab extract likely caused this lower viscosity, and tomato paste, especially its pectic substances, lowered carbohydrate levels.

\section{Free amino acid contents and profiles}

Table 5 shows the free amino acid contents and profiles of optimized blue crab sauce; these were examined because they can influence the taste of sauces containing proteinous ingredients. Quantitative analysis used an amino acid analyzer and the OPDA method (Church et al. 1983), and revealed that the optimized sauce had a significantly higher total free amino acid content $\left(p=0.015, \mathrm{R}^{2}=91.02 \%\right)$ than the other sauces. Results of free amino acid content in the American-style and optimized sauces indicate that the taste of sauce is related to free amino acid sources and treatment. Addition of blue crab block

Table 5. Free amino acid profiles and contents of sauces $(\mathrm{g} / 100 \mathrm{~g}$ solid)

\begin{tabular}{|c|c|c|c|}
\hline & $\begin{array}{c}\text { American } \\
\text { sauce }\end{array}$ & $\begin{array}{l}\text { Control } \\
\text { sauce }\end{array}$ & $\begin{array}{c}\text { Optimized } \\
\text { sauce }\end{array}$ \\
\hline Phosphoserine & 0.121 & 0.283 & 0.718 \\
\hline L-Aspartic acid & 0.235 & 0.039 & 0.192 \\
\hline L-Threonine & 0.063 & 0.047 & 0.097 \\
\hline L-Serine & 0.065 & 0.028 & 0.082 \\
\hline Asparagine & 0.437 & 0.087 & 0.529 \\
\hline L-Glutamic acid & 0.951 & 0.284 & 0.775 \\
\hline L-Glycine & 0.013 & 0.375 & 0.293 \\
\hline L-Alanine & 0.236 & 0.262 & 0.381 \\
\hline L-a-Aminobutyric acid & 0.005 & 0.006 & \\
\hline L-Valine & 0.039 & 0.075 & 0.116 \\
\hline L-Isoleucine & 0.047 & 0.041 & 0.077 \\
\hline L-Leucine & 0.029 & 0.065 & 0.096 \\
\hline L-Tyrosine & 0.034 & 0.035 & 0.079 \\
\hline L-Phenylalanine & 0.093 & 0.064 & 0.118 \\
\hline$\beta$-Alanine & 0.002 & & 0.002 \\
\hline y-Aminobutyric acid & 0.319 & 0.055 & 0.262 \\
\hline $\mathrm{NH}_{3}$ & 0.075 & 0.009 & 0.059 \\
\hline L-Orinithine & & 0.014 & 0.023 \\
\hline L-Lysine & 0.045 & 0.037 & 0.114 \\
\hline 1-Methyl-L-Histidine & & 0.038 & \\
\hline L-Hisidine & 0.029 & 0.011 & 0.029 \\
\hline L-Arginine & 0.222 & 0.094 & 0.788 \\
\hline Total & 3.059 & 1.947 & 4.833 \\
\hline$\overline{\mathrm{OPDA}^{\mathrm{a}}}$ & $2,578 \pm 0.09$ & $2,288 \pm 0.10$ & $3,282 \pm 0.04$ \\
\hline
\end{tabular}

${ }^{a}$ Expressed as D.L. lysine equivalents. should increase the free amino acid content and thereby explain how the optimized sauce provided an umami taste more so than the other sauces. Previous research (Kim et al., 1990; Han et al., 1996; Lee et al. 2001) reported that major free amino acids in blue crab extract included arginine, taurine, glycine, and proline; our results differed from these reports. The optimized sauce contained major free amino acids including glutamic acid, phosphoserine, asparagine, and arginine, and the sum of those amino acids was about $60 \%$ of the total free amino acid content. These results generally support profiles of seafood sauce reported by Lee (2004); the higher contents of glutamic acid $(0.775 \mathrm{~g} / 100 \mathrm{~g}$ solid) and arginine $(0.788 \mathrm{~g} / 100 \mathrm{~g}$ solid $)$ in the optimized sauce than in the control or American-style sauces likely create the umami and sweet flavors in the optimized sauce.

\section{References}

AOAC. 1990. Official Methods of Analysis 15th ed., Association of Official Analytical Chemists, Washington, D.C., pp. 784.

Choi, S.K. 2002. American sauce, In: Western Cuisine. Hyeungsul Pub. Co., Seoul, pp. 180.

Church, F.C., H.E. Sawisgood, D.H. Porter and G.L. Catignani. 1983. Spectro- photometric assay using ophthaldialdehyde of determination of proteolysis in milk and isolated milk proteins. J. Dairy Sci., 66, 1219-1227.

Fishken, D. 1983. Consumer-oriented product optimization. Food Technol., 37, 49-52.

Jeong, H.S., N.M. Joo and H.J. Chun. 2000. The free amino acid components and examinations on ther preference of Consomme by main ingredient and yield. Kor. J. Soc. Cook. Sci., 16, 203-209.

Han, Y.S., D.S. Lee, S.I. Kim, D.S. Kim and J.H. Pyeun. 1996. Nitrogenous constituents in the extract of crabs caught in the Korean adjacent sea. Korean J. Soc. Food Cook. Sci., 12, 469-480.

Hu, R. 1999. Food process modeling and optimization. In: Food Product Design. Technomic Pub. Co. Inc., Lancaster, pp. 35-124.

Kim, Y.M., Y.C. Lee, J.G. Koo and D.S. Kim. 1990. Preparation of the hydrolyzate using crab byproduct after water extraction. Bull. Kor. Fish. Soc., 23, 77-86.

Kim, S.K. and S.J. Lee. 1999. Optimization of brown sauce preparation by response surface methodology and sensory test. J. Kor. Soc. Agric. Chem. Biotechnol., 42, $58-62$.

Lee, G.D. and Y.J. Jeong. 1999. Optimization on organolep-tic properties of red pepper jam by response surface methodology. J. Kor. Soc. Food Sci. 
Nutr., 28, 1269-1274.

Lee, G.D., J.E. Lee and J.H. Kwon. 2002. Application of response surface methodology in food industry. Food Sci. Ind., 33, 33-44.

Lee, K.H., K.I. Lee, Y.N. Lee and H.Y. Park. 2002. Sensory and mechanical characteristics of brown sauce by different ratio of ingredients. Kor. J. Soc. Food Cook. Sci., 18, 637-643.

Lee, K.I. 2004. The quality characteristics of sauce made with shrimp or crab. Kor. J. Soc. Food Cook. Sci., 20, 164-169.

Lee, P.Z., J.C. Lee, D.S. Jung, H.C. Yang and J.B. un. 2001. Chemical composition of blue crabs preserved in sauce. Kor. J. Food Sci Technol., 33, 714-719.

Love J. 1994. Product acceptability evaluation. Ch. 13. In: Advances in Meat Research: Quality attributes and their measurement in meat, poultry and fish products, Vol. 9. Pearson, A.M. and T.R. Dutson eds. Blackie Academic \& Professional, London, pp. 337-358.

Moskowitz, H.R. 1994. Product optimization: approaches and application. In: Measurement of Food Preferences. MacFie H.J.H. and D.M.H. Thomson eds. Blackie Academic \& Professional, London, pp. 97. 136.

Minitab User's Guide \#1. 2000. Data, Graphics and
Macors. Minitab Inc.

Minitab User's Guide \#2. 2000. Data Analysis and Quality Tools. Minitab Inc.

Minitab Rowlet, R. and Murphy. 1981. A convenient spectrophotometric method for the kinetic analysis of the enzymatic hydrolysis of $\mathrm{N}$-acyl peptides using ophthaldi- aldehyde. Anal. Biochem., 112, 163-167.

Oh, C. 2000 . Sensory properties and viscosity of bechamel sauce by cooking methods and ratio of raw materials. Kor. J. Food and Nutr., 13, 307-311.

Prinyawiwatkul, W., K.H. Mcwatters, L.R. Beuchat and R.D. Phillips. 1997. Physicochemical and sensory properties of chicken nuggets extended with fermentation cfowpea and peanut flours. J. Agri. Food Chem., 45, 1891-1898.

Scheffe, H. 1958. Experiments with mixtures. J. Roy. Stat. Soc., B20, 344-360.

Sidel, J.L. and H. Stone. 1983. An introduction to optimization research. Food Technol., 37, 36-38.

Van Laack. R.L.J.M., B.W. Berry and M.B. Solomon. 1996 Variations in internal color of cooked beef patties. J. Food Sci., 61, 410-414.

(Received July 2005, Accepted December 2005) 